\title{
Serratula coronata (Asteraceae) - a new species record for the flora of Azerbaijan
}

\author{
Arzu Y. HUSEYNOVA, Parvin N. AGHAYEVA, Parvana Kh. QARAKHANI, Valida M. ALI-ZADE \\ Institute of Botany, National Academy of Sciences of Azerbaijan \\ Badamdar Highway 40, Baku AZ1004, Azerbaijan \\ vm_alizade@yahoo.com
}

Huseynova A.Y., Aghayeva P.N., Qarakhani P.Kh., Ali-zade V.M. 2019. Serratula coronata (Asteraceae) - a new species record for the flora of Azerbaijan. Ukrainian Botanical Journal, 76(1): 67-70.

Abstract. Serratula coronata (Asteraceae) is reported for the first time for the flora of Azerbaijan. The species was first found during the field surveys in 2012 in the forest edge near the village of Qonaqkend in Quba District of Azerbaijan, and later (in 2014) also discovered between Arafsa and Leketaq villages in the Nakhchivan Autonomous Republic. Data on distribution of species of Serratula sensu lato in the Caucasus are briefly reported and summarized. Diagnostic characters distinguishing $S$. coronata from other related taxa are provided. Plant communities with participation of $S$. coronata in Azerbaijan are characterized. Recent data on taxonomy of Serratula and related taxa are briefly discussed. Keywords: Asteraceae, Azerbaijan, biogeography, flora, Serratula, taxonomy

Гусейнова А.Й., Агаєва Р.Н., Гарахані Р.Х., Алі-заде В.М. Serratula coronata (Asteraceae) - новий вид для флори Азербайджана. Український ботанічний журнал, 76(1): 67-70.

Інститут ботаніки НАН Азербайджана

Бадамдарське шосе 40, Баку AZ1004, Азербайджан

Abstract. Serratula coronata (Asteraceae) вперше наводиться для флори Азербайджана. Цей вид був знайдений під час польових обстежень у 2012 р. на лісовій галявині біля с. Гонагкенд у Губинському районі Азербайджана, а пізніше (в 2014 р.) - також між с. Арафса і Лекетаг у Нахічеванській Автономній Республіці. В статті стисло викладено дані про поширення видів Serratula на Кавказі. Подано діагностичні ознаки, які відрізняють S. coronata від інших споріднених таксонів. Наведено характеристики угруповань рослин із участю $S$. coronata в Азербайджані. Отримані результати обговорюються у контексті сучасних даних про таксономію та філогенію Serratula і споріднених таксонів. Ключові слова: Азербайджан, поширення, систематика, флора, Asteraceae, Serratula

The family Asteraceae (Compositae, nom. altern.) was reported to be represented in the flora of Azerbaijan by ca. 580 species belonging to 125 genera (Agadjanov, 1961); however, the exact numbers of species and genera are subject to changes due to recent changes in taxonomy and nomenclature. Several genera and species of the family, such as Centaurea L., Pyrethrum Zinn. sensu stricto (now Tanacetum L. sensu lato), etc., were studied in Azerbaijan in detail (Askerova, 1970; Qusenova et al., 2013, 2014; Mustafayeva, 2013; Mustafayeva et al., 2017); however, some groups of the family are still insufficiently known in the country. In the $20^{\text {th }}$ century, seven species of Serratula $\mathrm{L}$. sensu lato were reported for the territory of Azerbaijan (Agadjanov, 1961): S. quinquefolia M.Bieb. ex Willd., S. coriacea Fisch. \& C.A.Mey., S. radiata (Waldst. \& Kit.) M.Bieb., S. transcaucasica (Bornm.) Sosn. ex Grossh., S. caucasica Boiss., S. xeranthemoides M.Bieb., and S. serratuloides (Fisch. \& C.A.Mey. ex DC.) Takht.

(C) A.Y. HUSEYNOVA, P.N. AGHAYEVA, P.Kh. QARAKHANI, V.M. ALI-ZADE, 2019
Eight species of Serratula were reported from the Caucasus, including $S$. coronata L., S. erucifolia (L.) Boriss., S. radiata, S. haussknechtii Boiss., S. coriacea, S. quinquefolia, S. serratuloides (Fisch. \& C.A.Mey.) Takht., and $S$. caucasica Boiss. Serratula coronata was mentioned in the Conspectus florae Caucasi (2008) for central and western parts of the Caucasus, but not for Azerbaijan, which is located in the Southern Caucasus. Of those species reported in the Conspectus, $S$. transcaucasica was synonymized with $S$. haussknechtii and $S$. xeranthemoides with $S$. erucifolia. Other species were recorded for Azerbaijan.

The concept of the genus has changed recently and all Azerbaijani species except one ( $S$. coriacea) were transferred to the genus Klasea Cass. Now they are recognized as Klasea quinquefolia (Willd.) Greuter \& Wagenitz (Serratula quinquefolia), K. radiata (Waldst. \& Kit.) Á. Löve \& D.Löve (S. radiata), K. haussknechtii (Boiss.) Holub (S. transcaucasica), K. caucasica (Boiss.) Greuter ( $S$. caucasica), K. erucifolia (L.) Greuter \& Wagenitz ( $S$. xeranthemoides), and $K$. serratuloides 

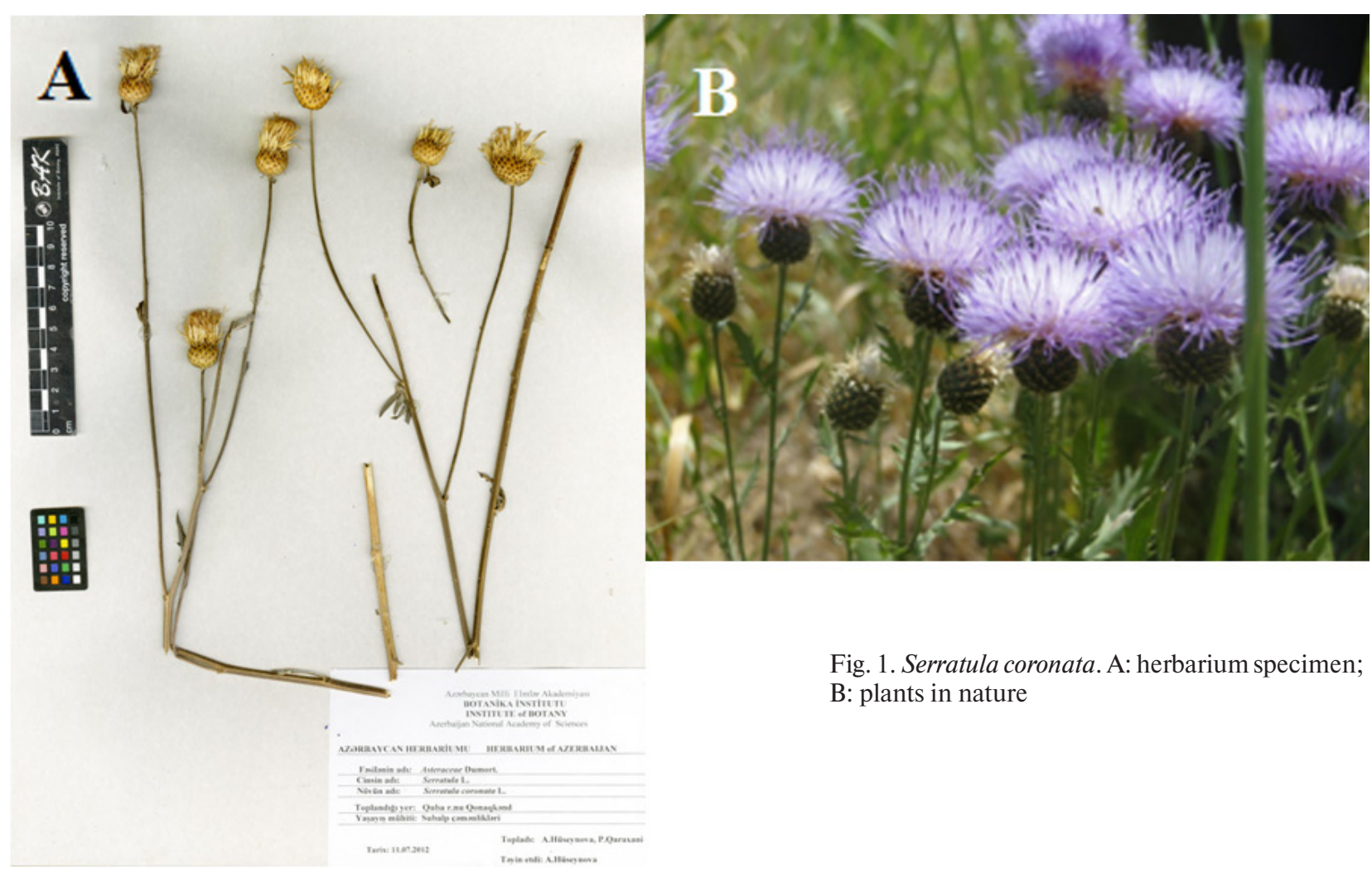

Fig. 1. Serratula coronata. A: herbarium specimen; B: plants in nature

(DC.) Greuter \& Wagenitz (S. serratuloides) (see Wagenitz, 1959, 1975; Wagenitz, Hellwig, 1996). Serratula coronata and $S$. erucifolia have not been yet reported from Azerbaijan.

Reliable diagnostic characters for identification of species of Serratula and Klasea include pollen types, chromosome numbers, along with arrangement of florets, seriate pappus, phyllaries, apendages, etc., but in general identification of species belonging to that group of Asteraceae is complicated. Eight pollen types were distinguished among taxa of the subtribe Centaureinae and, according to the pollen evolution, the genera Serratula, Crupina (Pers.) DC., Rhaponticoides Vaill., Psephellus Cass., Centaurea, and the Acrocentron and Jacea groups of Centaurea sensu lato were evolutionarily ranked based on their main pollen types by Wagenitz (1955). Later, Serratula, Crupina and Rhaponticoides were accepted as "primitive" (with mainly ancestral pollen characters), Psephellus (including P. dealbatus (Willd.) K.Koch = Centaurea dealbata Willd., and related taxa), the Centaurea Cyanus and Centaurea Montana groups - as intermediate, but the Acrocentron and Jacea groups of Centaurea - as advanced types.
The Serratula type with spiny pollen grains was placed in the evolutionarily basal (early-branching) part of the cladogram of Centaureinae (Garcia-Jacas et al., 2001).

Progress in taxonomy, beginning from the last decades of the $20^{\text {th }}$ century, especially due to molecular phylogenetic studies, brought more clarity to the taxonomic positions of genera, also necessitating numerous taxonomic changes and nomenclatural rearrangements within subtribes, tribes, and genera. Recent molecular phylogenetic studies indicated that the genus Serratula, as traditionally understood, is not a monophyletic group (Martins, Hellwig, 2005; Martins, 2006; Dogan et al., 2015). In particular, the segregate genus Klasea is currently recognized as distinct from Serratula sensu stricto (Ranjbar et al., 2015). However, the species $S$. coronata remains in the genus Serratula sensu stricto.

Herbarium specimens were collected in subalpine meadows of Qonaqkend village in Quba District, at elevation $1900 \mathrm{~m}$ above sea level [a.s.l.] (GPS coordinates $\mathrm{N} 41^{\circ} 12^{\prime} 03.8^{\prime \prime}$, E048 $13^{\prime} 21.7^{\prime \prime}$, collection date 11 August 2012) and between Arafsa and Leketaq villages in Nakhchivan Autonomous Republic of 
Azerbaijan at elevations $1700-1800 \mathrm{~m}$ a.s.l. (GPS coordinates $\mathrm{N} 41^{\circ} 05^{\prime} 546^{\prime \prime}$, E048 $27^{\prime} 37.0^{\prime \prime}$, collection date 23 July 2014). In both cases the plants were found growing under meso-xerophytic conditions. Specimens were identified based on morphology and taking into account the main diagnostic characters.

Serratula coronata thus represents a new species record for the flora of Azerbaijan (Fig. 1, A, B). This species in Quba District was found in plant communities growing together with Campanula caucasica M.Bieb., C. latifolia L., C. rapunculoides L., C. stevenii M.Bieb., Centaurea iberica Trevir. ex Spreng., Cyanus cheiranthifolius (Willd.) Soják (Centaurea cheiranthifolia Willd.), Festuca ovina L., Erigeron orientalis Boiss., Gentiana verna L., Nonea alpestris (Steven) G.Don, N. dagestanica Kusn., Primula amoena M.Bieb., P. auriculata Lam., Thymus collinus M.Bieb., and Veronica biloba L. The plant was distrubuted in small groups. A large population of the species was found in Nakhchivan growing in assosiation with Rumex alpinus L., Polygonum cognatum Meisn., Astragalus karjaginii (Boriss.) Boriss., and Pentanema britannicum (L.) D.Gut.Larr. et al. (Inula britannica L.). The plants mainly occur in forests, forest edges, on mountain slopes, and in salty and mountain meadows.

\section{Conclusions}

Asteraceae/Compositae has been studied in Azerbaijan mainly during the 1950s-1960s and, based on collected information and herbarium data, the eighth volume of the Flora of Azerbaijan has been compiled (Flora Azerbaidzhana, 1961). This represents the main source for identification and analyzing the species of the family in the flora of Azerbaijan. As mentioned above, seven species of Serratula sensu lato recorded in the Flora of Azerbaijan (1961) and eight species in the Conspectus florae Caucasi (2012). Most of them were recently transferred to the segregate genus Klasea. Currently only two species known from Azerbaijan, S. erucifolia and $S$. coronata, are still considered as belonging to the genus Serratula sensu stricto.

As well known, over the last 40 years large-scale changes were introduced in Asteraceae systematics; in particular, tribal limits have been significantly reshaped (Funk et al., 2009). Considering taxonomic and nomenclatural changed proposed and accepted for Asteraceae, there is the urgent need to analyze the family in Azerbaijan at the level of tribes and genera. The number and list of species recorded in the flora of the country should be also further updated and specified in the future.

\section{Acknowledgments}

We are grateful to Sergei L. Mosyakin (M.G. Kholodny Institute of Botany, NAS of Ukraine) for his valuable comments on the manuscript.

\section{REFERENCES}

Agadjanov S.D. Serratula. 1961. In: Flora of Azerbaijan, vol. 8. Ed. I.I. Karyagin. Baku: Academy of Sciences of Azerbaijan SSR, pp. 423-428. [Агаджанов С.Д. 1961. Serratula. В кн.: Флора Азербайджана, т. 8. Ред. И.И. Карягин. Баку: Изд-во АН Азерб. ССР, с. 423-428].

Askerova R.K. 1970. To the palynological characteristics of the tribe Cichorieae fam. Compositae. Botanical Journal, 55(5): 660-668. [Аскерова Р.К. 1970. К палинологической характеристике трибы Cichorieae сем. Сотровіtае. Ботанический журнал, 55(5): 660-668].

Conspectus florae Caucasi, vol. 3(1). Ed. A.L. Takhtajan. 2012. St. Petersburg; Moscow: KMK Scientific Press, 469 pp. [Конспект Флоры Кавказа, т. 3(1). Ред. А.Л. Тахтаджян. 2012. СПб; М.: Тов-во науч. изданий KMK, 469 c.].

Dogan B., Duran A., Şeker M., Çetin Ö., Martin E. 2015. Study of phylogenetic relationship of Turkish species of Klasea (Asteraceae) based on ISSR amplification. PhytoKeys, 56: 29-40.

Flora Azerbaidzhana. 1961. Vol. 8. Ed. I.I. Karyagin. Baku: Academy of Sciences of Azerbaijan SSR, 688 pp. [Флора Азербайджана. 1961. Т. 1. Ред. И.И. Карягин. Баку: Изд-во АН Азерб. ССР, 688 с.].

Funk V.A., Susanna A., Stuessy T.F., Robinson H. 2009. Classification of Compositae. In: Systematics, evolution, and biogeography of Compositae. Eds V.A. Funk, A. Susanna., T.F. Stuessy, R.J. Bayer. Vienna: International Association for Plant Taxonomy (IAPT), pp. 171-192.

Gabreliyan E.S. 2012. Serratula. In: Conspectus florae Caucasi, vol. 3(1). Ed. A.L. Takhtajan. St. Petersburg; Moscow: KMK Scientific Press, pp. 280-281. [Serratula. In: Конспект Флоры Кавказа, т. 3(1). 2012. Ред. А.Л. Тахтаджян. СПб; Москва: Тов-во науч. изданий KMK, c. 280-281].

Garcia-Jacas N., Susanna A., Garnatje T., Vilatersana R. 2001. Generic delimitation and phylogeny of the subtribe Centaureinae (Asteraceae): A combined nuclear and chloroplast DNA analysis. Annals of Botany, 87: 503-515.

Martins L. 2006. Systematics and biogeography of Klasea (Asteraceae - Cardueae) and a synopsis of the genus. Botanical Journal of the Linnean Society, 152: 435-464.

Martins L., Hellwig F.H. 2005. Systematic position of the genera Serratula and Klasea within Centaureinae (Cardueae, Asteraceae) inferred from ETS and ITS sequence data and new combinations in Klasea. Taxon, 54(3): 632-638. 
Mustafayeva S.C. 2013. Asteraceae Bercht. et J. Presl fəsiləsinin öyrənilməsinə dair. AMEA-nın Xəbərlar, Biologiya va Tibb Elmlori, 68(1): 17-23. [Mustafayeva S.C. 2013. Study on Asteraceae Bercht. et J. Presl family. Proceedings of ANAS, Biology and Medical Sciences, 68(1): 17-23].

Mustafayeva S.J., Aghayeva S.O., Bakhshaliyeva K.F., Novruzov E.N. 2017. Investigation of component composition of essential oils of Pyrethrum parthenifolium Willd. and Senecio vulgaris L. Proceedings of the Institute of Botany, ANAS, 37: 89-95.

Ranjbar M., Negaresh K., Karamian R. 2015. A synopsis of Klasea sect. Schumeria (Asteraceae, Cardueae) in Iran. Novon, 24(2): 186-198.

Wagenitz G. 1959. Pollen Morphologie und Systematik in der Gattung Centaurea L. s. 1. Flora, 14: 213-279.

Wagenitz G. 1975. Centaurea. In: Flora of Turkey and the East Aegean Islands, vol. 5. Ed. P.H. Davis. Edinburgh: Edinburgh Univ. Press, pp. 465-585.
Wagenitz G., Hellwig F.H. 1996. Evolution of characters and pahylogeny of the Centaureinae. In: Compositae: Systematics. Proceedings of the International Compositae Conference. Eds D.J.N.Hind, H.G.Beentje. Kew: Royal Botanic Gardens, pp. 492-510.

Huseynova A.Yu., Qarakhani P.Kh., Nabieva P.N. 2013. To nomenclature and systematics of some species of the genus Centaurea L. (Asteraceae Dumort.). Bulletin of the Moscow State Regional University. Natural Sciences Series, 3: 19-22. [Гусейнова А.Ю., Гарахани П.Х., Набиева П.Н. 2013. К номенклатуре и систематике некоторых видов рода Centaurea L. (Asteraceae Dumort.). Вестник Московского государственного областного университета. Серия Естественные науки, 3: 19-22].

Huseynova A.Yu., Qarakhani P.Kh., Mekhtiyeva N.P. 2014. New species of the genus Centaurea (Asteraceae). Botanical Journal, 99(3): 350-352 [Гусейнова А.Ю., Гарахани П.Х., Мехтиева Н.П. 2014. Новый вид рода Centaurea (Asteraceae) из Азербайджана. Ботанический журнал, 99 (3): 350-352].

Recommended for publication by

Submitted 20.08.2018 